\title{
Thematic Progression of Higher Education Advertorials: A Case Study in English and Bahasa Indonesia
}

\author{
Eva Tuckyta Sari Sujatna \\ Universitas Padjadjaran, Indonesia \\ Kasno Pamungkas \\ Universitas Padjadjaran, Indonesia \\ Heriyanto Heriyanto \\ Universitas Padjadjaran, Indonesia
}

\begin{abstract}
Many researchers do their research on advertorial but the one discussing thematic progression in advertorial is still limited. The word advertorial comes from two English words; they are advertisement and editorial as an English blending words. This research data focuses on higher education both in English and Bahasa Indonesia advertorials. This article tries to figure out the types of the thematic progression and the types of the theme in advertorial for higher education both in English and Bahasa Indonesia advertorials. The research method applied in this research is descriptive analysis. The data taken from advertorial both in English and Bahasa Indonesia are collected and they are analyzed based on the Halliday's theory of thematic progression and the types of the each theme found in the data. The research discusses two main questions; firstly what type of thematic progression found in Bahasa Indonesia and English advertorials for higher education, and secondly what types of theme found in each theme in English and Bahasa Indonesia for higher education advertorial. After doing classification and analyzing the data, it is found that the thematic progression in English and Bahasa Indonesia advertorials has different pattern. The dominant thematic progression found in Bahasa Indonesia advertorial for higher education is zigzag theme pattern while the dominant one found in English advertorial for higher education is reiteration theme pattern. From the data found, both of Bahasa Indonesia or English advertorial, it is found that the dominant theme found in each clause of the data is ideational or topical theme.
\end{abstract}

Keywords: thematic progression, advertorial, zigzag pattern, reiteration pattern, ideational theme, topical theme

\section{INTRODUCTION}

In their development, research on linguistics do not always stand alone in their theoretical area but have interacted with other disciplines, known as macro or applied linguistics. In such a kind of study, linguistics could be interacted with education, tourism, information technology, teaching, health sciences etc. In health sciences, for example, Pamungkas \& Abdulah (2017) study the linguistics-based product naming methods of some over the counter (OTC) medicines in Indonesia and their impacts to companies and consumers.

Furthermore, (Pamungkas et al. 2018) also tries to interact linguistics with information technology by identifying psychological subjects in News Headlines of Universities' Website in Indonesia. Since this study has similarity on Systemic Functional Linguistics (SFL), this study is a preliminary research which discusses the thematic progressions in Bahasa Indonesia advertorial and English advertorial employing the SFL crossed with communication studies. As 
everybody knows that the role of the English language in globalization and the impact of globalization on English are complex issues which require close scrutiny (Sharifian 2016).

The word advertorial, in the field of communication, comes from the two words; advertisement and editorial. By understanding the thematic progression applied in the advertorial, the readers will learn the writers' style in communicating their ideas both in Bahasa Indonesia and English advertorial for higher education to the readers. Communication, as Levine and Edelman (1993) in Mulyana (2012) is the process of sharing through verbal and nonverbal behavior. From the definition, it is understood that advertorial as a verb language is a part of communication. In communicating, the speakers or the writers are influenced by their own culture as mentioned by Condon and Yousef (1985) in Mulyana (2012),

"Communication involves expectation, perception, choice, action, and interpretation. Every time you communicate with someone, there is no doubt that he or she comes from a cultural environment. This means that what he or she says and the way he or she behaves is influenced by his or her culture, although this doesn't mean that all members of the culture behave in exactly the same way."

This research tries to describe the culture of the two different nations, English and Indonesian; their own ways in communicating their culture through the advertorial.

The word advertorial, in English, comes from the two English words; advertisement and editorial. It is found in the Merriam Webster that advertorial is "an advertisement that imitates editorial format", and this word has been one of the English vocabularies since 1946. In Kamus Besar Bahasa Indonesia (2003) as a dictionary of Bahasa Indonesia the word advertorial is defined as "iklan yang merupakan berita (bukan gambar atau poster)". The definition means that the word advertorial in Bahasa Indonesia is a news as a promotion (neither a picture nor a poster). In other way, advertorial is a promotion text which is a journalism form to introduce or to promote products or services to the readers in mass media. So the advertorial is one of the communication tools between writers and readers.

Relating to the types of advertorial (Iriantara \& Surachman, 2011, p. 128-129), the advertorial could be different from products, services, corporate, and government. The advertorial of products as the first type, introduce the types of products to the readers. Secondly, the advertorial of services offer the kind of services to the readers. Thirdly, the advertorial of corporate discusses the existence and the activities of the cooperation or the institution while, the advertorial of the government contains of the activities of the government or the potency of one area.

In this preliminary research, the writers discuss the second type of advertorial since the higher education advertorial is one of the advertorial of services. The advertorial of higher education mentioned are both in English and Bahasa Indonesia languages.

\section{Advertorial}

Today, advertorials is as commonly referred by magazine advertising supplements (Stout et al. 1989, 960). As described by Kim, Pasadeos, and Barban (2001), an advertorial is "a print advertisement disguised as editorial material". It is in line with Brown and Waltzer (2004) arguing that the advertorial is an important tool used by organized interests to create an advantageous public opinion climate regarding controversial issues.

Advertorials are designed to be more informational, in line with material feature, they typically have longer copy (Cameron \& Ju-Pak, 2000). The way of writing an advertorial, according to 
(Iriantara and Surachman 2011, 134-138), is related to $5 \mathrm{~W}+1 \mathrm{H}$; What, Who, Where, When, Why and How. The structure of the text is divided into introduction, body, and closing. In the introduction part, the writer tries to attract the reader attention to the article. In this part, the writer could apply the style of narrative text, descriptive text, questions, epigrams, quotations, or greetings. The second part, is the body of the advertorial. In this part, the writers discuss the content of the advertorial. The third part is closing; it could be contained of questions, statements, or conclusion of the advertorial. In this article the writers try to analyze the advertorial both in Bahasa Indonesia and English related to the theme progression, including the theme patterns and the elements of the theme.

\section{Systemic Functional Linguistics}

Systemic Functional Linguistics (SFL) was introduced by Halliday through his well-known book entitled 'An Introduction to Functional Grammar'. The book was firstly published in 1985 and it was being revised in 1994 as the second edition, and in 2004 the book was revised again as the third edition. In SFL approach, it is stated that language is a system of meaning that relates to three different metafunctions. The metafunctions are textual meaning, interpersonal meaning, and ideational meaning (Sujatna, 2012).

Ideational meaning relates to clause as representation. While in the clause as exchange that relates to transitivity, it involves three main elements; process, participant, and circumstance. The second metafunction, interpersonal meaning relates to mood and residue while the mood itself relates to subject and finite, and the residue relates to predicator, complement, and adjunct. One of linguistic features which can be applied to construct a good rapport with audience in text is interpersonal metadiscourse. As Sukma and Sujatna (2014:16) argue that this feature is closely related to persuasive writing since it specifically explores interpersonal relationship and interaction between addresser and addressee. The third metafunction is textual meaning as the focus the research. This metafunction relates to theme and rheme.

Theme is argued by Halliday (2004: 64) as the term that was taken from Prague school and it was defined as "the element which serves as the point of departure of the message; it is that which locates and orients the clause within its context." Similar to the argumentation, Sujatna (2013: 5) argued that "psychological subject is a subject that concerns of the message. It is called psychological because it was what the speaker had in his mind to start with, when embarking on the product of the clause. The psychological subject is usually called theme." It is mentioned that theme that theme is also called psychological subject while the theme is the rest of the theme as argued by Sujatna (2013: 13) "The rest of the clause tells the reader something about the theme and 'the rest of the clause' called rheme." From the explanation, theme and theme could be considered as the main parts in understanding the message of each clauses that written by the writer. As a paragraph the relation of one clause to another should be tied up. It could be seen from the thematic progression of the paragraph.

A writer puts the theme first and this orients the reader to what is about to be communicated. Relating to the type of theme itself, it has three different types of theme; they are ideational or topical theme, textual, and interpersonal theme. Ideational or topical theme could be marked and unmarked theme. The unmarked theme could be realized as pronoun, common noun, proper noun or nominalization, while the marked theme could be realized as predicator, complement, or adjunct. The second type of theme, textual theme, could be categorized into continuative, conjunctive adjunct, or conjunction. Interpersonal themes, as the the third type of theme, are ones that indicate something about the relationship between speaker and hearer (Sujatna, 2013: 20). Interpersonal themes could be realized by three different types; they are modal adjunct, vocatives, and finite or Wh-element/ verbal operator (in interrogative). 
According to Deterding and Poedjosoedarmo (2001) in Sujatna (2013) there are four different types of thematic progression in a paragraph. The four types are described in the following

\section{Type 1}

The most important technological advance of the 20th century is the computer. Computers now not only sit on desktops in offices and at home; they also regulate temperature in our homes, control the function of washing machines and automobiles ...

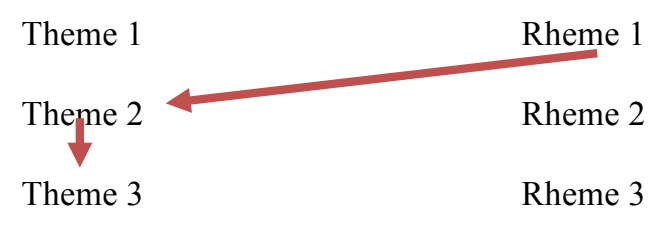

\section{Type 2}

Noam Chomsky, author of Aspects of the Theory of Syntax, revolutionized linguistics. He also happens to be well-known for his political views. In fact, he is better-known to laymen for his political views than he is for his revolutionary linguistic ideas.

$\begin{array}{ll}\text { Theme } 1 & \text { Rheme 1 } \\ \text { Theme 2 } & \text { Rheme 2 } \\ \text { Theme 3 } & \text { Rheme 3 } \\ \text { Theme 4 } & \text { Rheme 4 }\end{array}$

\section{Type 3}

The museum is located in the centre of town near the square. This square is a common destination of tourist buses. The buses, all belonging to the Island Tour Bus Company, are driven by the tour guides. These guides get off at each stop with the passengers and explain the sights to them.

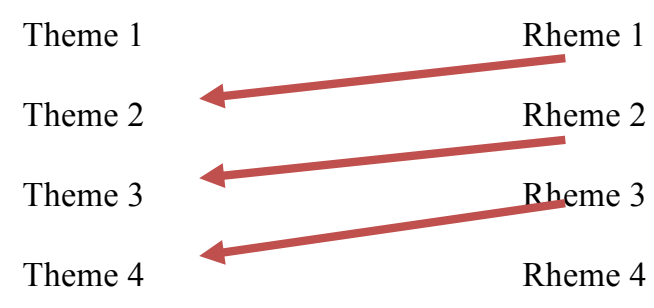

\section{Type 4}

Everybody likes Mamma Mia. Kids like Mamma Mia. Teenagers love Boogie Burgers. Parents love Boogie Burgers. Grandparents love Boogie Burgers.

$\begin{array}{ll}\text { Theme } 1 & \text { Rheme } 1 \\ \text { Theme } 2 & \text { Rheme } 2 \\ \text { Theme } 3 & \text { Rheme } 4 \\ \text { Theme } 4 & \text { Rheme } 5\end{array}$


Type 1 describes that rheme 1 (the theme in the first clause) could be theme 2 (theme in the second clause) while the type 3 describes that every theme could be a theme, in other words theme 1 becomes theme 2, rheme 2 becomes theme 3, and rheme 3 becomes theme 4 .

The $\longrightarrow$ thematic progression in type 2 and type 4 are different from type 1 and type 3 , the type 2 describes that theme 1 becomes theme 2 , theme 2 becomes theme 3 , and theme 3 becomes theme 4 , and so on while the type 4 the rheme 1 becomes the rheme 2 , the rheme 2 becomes rheme 3, rheme 3 becomes rheme 4, and so on and so forth.

Besides the thematic progression that mentioned by Deterring and Poedjosoedarmo (2001), earlier Paltridge (2000) describes another types of thematic progression in Sujatna (2013: 28).

\section{Type 1}

Theme

There bat

It

There

Bats

They

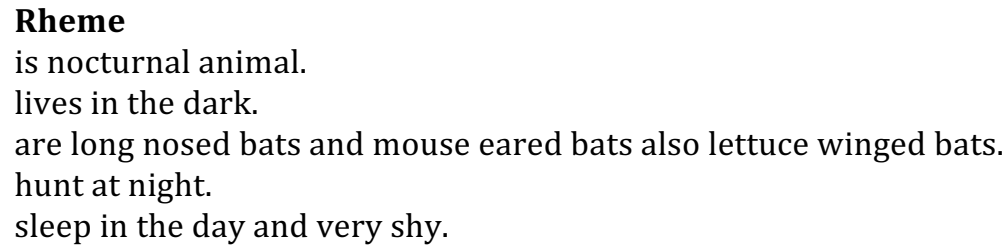

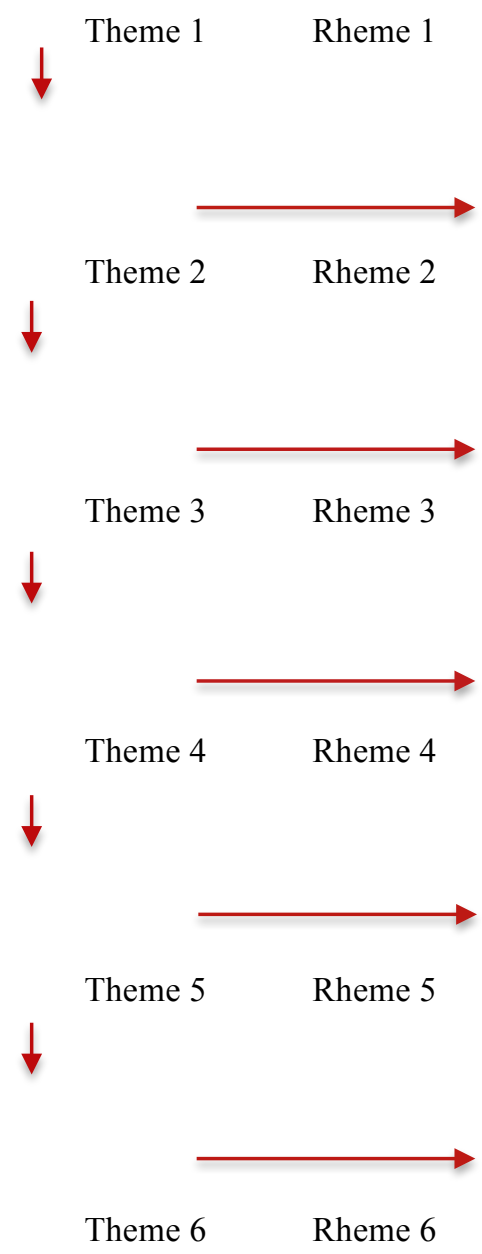

Theme $6 \quad$ Rheme 6 


\section{Type 2}

Theme

The American Psychological

This format

Theme

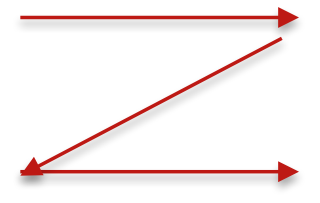

Theme

\section{Type 3}

\section{Theme}

When Japanese people

They

The two alphabets

The Chinese ideograms

Hiragana

Katakata

Theme 1

\section{Rheme 1}

Theme

Theme 3

Theme 4

Theme 5

Theme

Theme

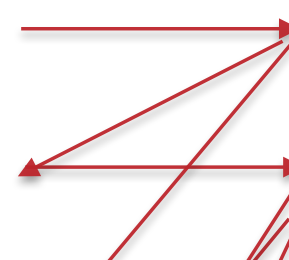

2
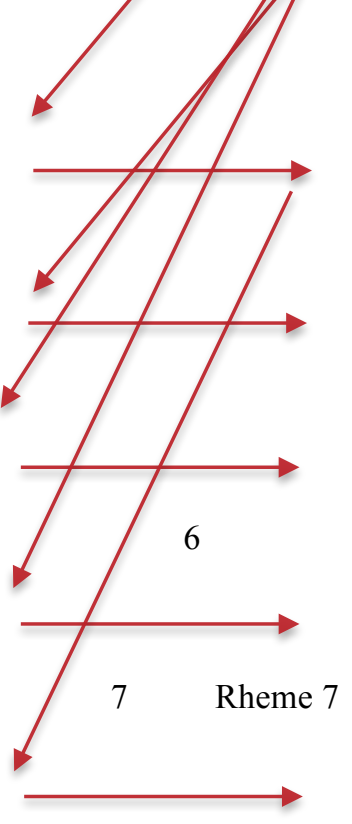

\section{Rheme}

write their language.

use a combination of two separate alphabets as well as ideograms borrowed from Chinese are called hiragana and katakana.

are called kanji.

represents the 46 basic sounds that are made in the Japanese language.

represents the same sounds as hiragana.

Rheme 2

Rheme 3

Rheme 4

Rheme 5

Rheme 6

Theme

$8 \quad$ Rheme 8 
Paltridge (2000) in Sujatna (2013) named it as pattern type 1 is as reiteration theme/ constant theme, type 2 is as zigzag theme/ linear theme, and type 3 is as multiple theme/ split theme. From the two patterns offered by the two linguists, Deterding and Poedjosoedarmo (2001) and Paltridge (2000) it is concluded that the two classifications are important and both of them are complemented one another. Therefore, both of the theories are employed in this research.

\section{RESULT AND DISCUSSION}

This research applied some advertorial samples from both Bahasa Indonesia and English higher education advertorials. As a preliminary study, the data obtained from the opening part of the advertorial. The following are the data 1 and data 2 which taken from the opening part of the Bahasa Indonesia higher education advertorial.

\section{Data 1}

\section{Theme}

PT Telekomunikasi Indonesia, Tbk

(Persero) atau Telkom

TeSCA atau Telkom Smart Campus Award

Dengan adanya TeSCA, suatu

perguruan tinggi

Program yang berlangsung sejak

Dalam acara TeSCA 2013 di Hotel

Dharmawangsa 1 Mei 2013 lalu, Direktur Umum PT Telekomunikasi

Indonesia, Arief Yahya

Tiga parameter tersebut

Sejauh ini, TeSCA

Calibration berarti TeSCA

\author{
Rheme \\ menunjukan komitmennya untuk turut aktif dalam \\ kemajuan dunia pendidikan Indonesia melalui \\ program TeSCA. \\ merupakan program CSR PT Telekomunikasi \\ Indonesia berbentuk penghargaan yang diberikan \\ kepada perguruan tinggi negeri dan swasta di \\ seluruh Indonesia dalam aspek implementasi \\ information, communication \&Technology (ICT). \\ dapat mengukur diri mereka melalui parameter- \\ parameter yang memandu mereka menuju World \\ Class University. \\ didukung oleh Direktorat Jenderal Pendidikan tahun 2008 ini \\ Tinggi Kemdikbud, Asosiasi Perguruan Tinggi Ilmu \\ Komputer (Aptikom), dan Dewan Teknologi \\ Informasi dan Komunikasi Nasional (Detiknas). \\ memaparkan bahwa untuk menjadi suatu perguruan \\ tinggi yang berstandar internasional, ada tiga \\ parameter yang dapat memandu suatu perguruan \\ tinggi untuk menyandang taraf internasional. \\ adalahCalibration, Confident dan Credibility. \\ baru memenuhi satu parameter, yaitu Calibration. \\ sudah melakukan pengukuran tingkat pemanfaatan \\ teknologi informasi untuk proses belajar mengajar.
}

Source:

http://edukasi.kompas.com/read/2013/05/19/00002884/TeSCA..Bukti.Kepedulian.Telkom.pa da.Pendidikan

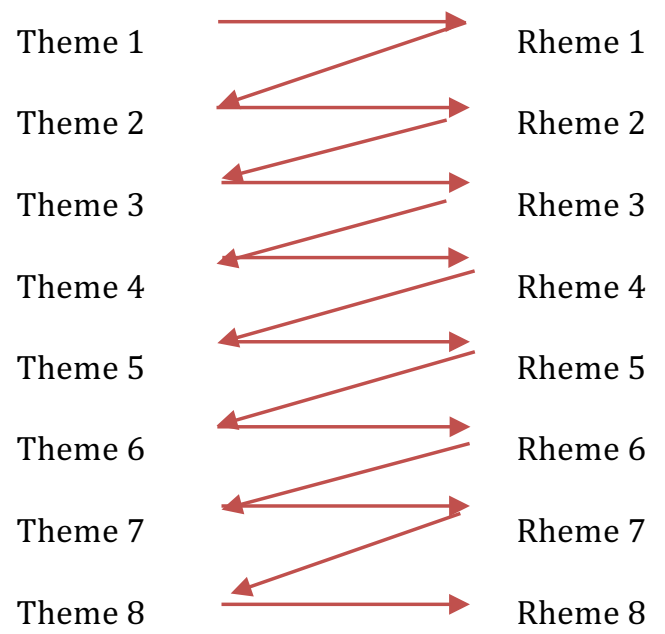


Data 1 describes that it is the part of the opening paragraph of the Bahasa Indonesia higher education advertorial. The data has eight clauses. The first clause has one theme and one rheme. The rheme in the first clause becomes the theme in the second clause, while the rheme in the second clause becomes the theme in the third clause. It happens to the rheme in the third clause becomes the theme in the fourth clause and the the rheme in the fourth clause becomes the theme in the fifth clause. It happens to the next clause after, up to the last clause, the eight clauses. It could be concluded that the data has zigzag pattern since every rheme in the earlier clause constantly becomes the theme of the next clause. From the data shown in Data 1, there are eight clauses and all theme types of the clause in Data 1 is ideational or topical theme.

\section{Theme}

Menimba ilmu di luar negeri

Salah satu negara yang kerap

Negara sakura ini

Salah satunya

\section{Rheme}

merupakan idaman sebagian besar pelajar

Indonesia.

menjadi tujuan pelajar Indonesia untuk

belajar adalah Jepang.

menyediakan banyak pilihan universitas bergengsi di dunia.

adalah Ritsumeikan Asia Pasific University

(APU) yang menjadi incaran banyak

pelajar asal Indonesia.

Source:

http://edukasi.kompas.com/read/2013/09/15/1409374/Tertarik.Kuliah.di.Ritsuimeikan.Asia. Pasific.University.

\section{Data 2}

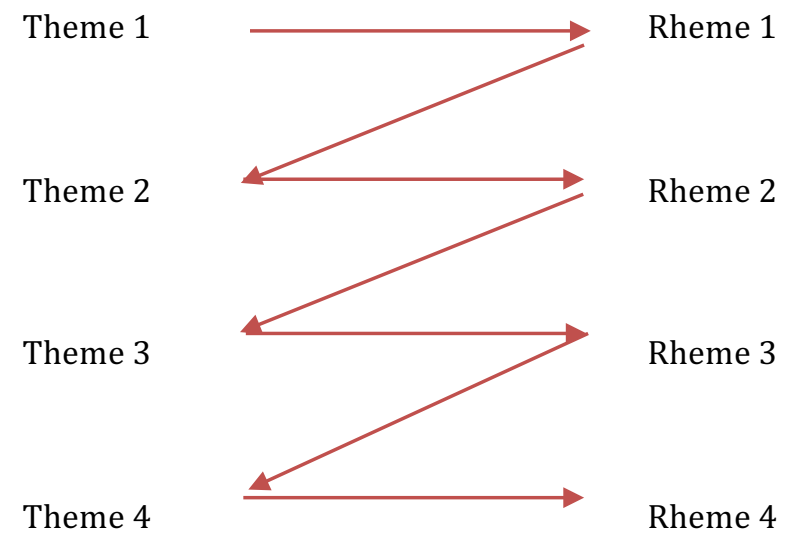

Data 2 is a description of thematic progression that is found in the data that has four clauses. The data is taken from the opening part of the Bahasa Indonesia higher education advertorial. The first clause has one theme and one rheme. The rheme in the first clause becomes the theme in the second clause, and the rheme in the second clause becomes the theme of the third clause, it also happened to the theme in the fourth clause that comes from the rheme in the third clause. From the two data described as higher education advertorial in Bahasa Indonesia, it is found that the pattern is zigzag or Type 2 (as described by Paltridge, 2000) and Type 3 (as described by Deterding and Poedjosoedarmo, 2001). From the data 1, that containing four clauses, it can be seen that all the theme types are ideational or topical.

The following are Data 3 and Data 4. Both of data are taken from the opening part of English higher education advertorials. 


\section{Theme}

KLC College: Healthcare, Business,

Education

Office Administration

They

Assistant program

(that)

\section{Theme}

is expanding the programs offered at its Whitby

Campus - two new career study programs Personal

Support Worker (PSW) and

will be introduced starting in March, 2012.

will be offered in addition to the Educational

has been offered since 2005 .

Source:

http://www.klccollege.ca/Data/editor/file/KLC\%20College\%2020Whitby\%20Campus\%20Exp anding.pdf

\section{Data 3}

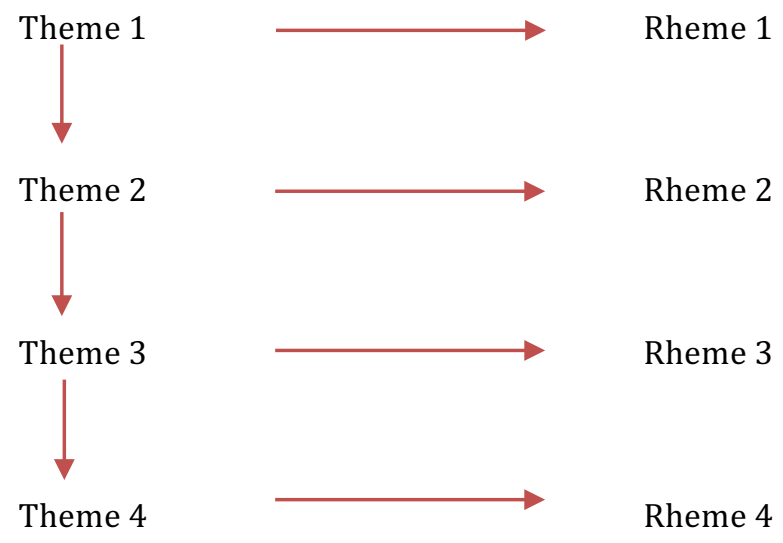

Data 3 describes that the opening paragraph as the data has four different clauses. Every clause has one theme and theme of each. From the pattern described, the theme in the first clause becomes the theme in the second clause, and the theme in the second clause becomes the theme in the third clause, but it does also happen to the theme in the fourth clause that comes from the theme in the third clause. From the data 3 it is shown the four clauses that containing ideational or topical theme of each clause.

\section{Theme}

Christianity Today

It

(It)

(It)

Every issue

(that)

Christianity Today

\section{Rheme}

is the definitive voice offering the most complete coverage of the Church in the world today.

informs,

counsels, and

challenges readers with interviews, feature articles, thoughtful essays and much more.

provides insightful commentary, penetrating interviews with leading Christian thinkers, and theological analysis on current issues, trends, people and news events

impact people of faith.

delivers honest, relevant commentary from a biblical perspective, covering the whole spectrum of choices and challenges facing Christians today.

Source: http://www.christianitytodayads.com/print-media/christianity-today/ 


\section{Data 4}

$\begin{array}{ll}\text { Theme } 1 & \text { Rheme } 1 \\ \text { Theme 2 } & \text { Rheme 2 } \\ \text { Theme } 3 & \text { Rheme 3 } \\ \text { Theme } 4 & \text { Rheme 4 }\end{array}$

Similar to data 3, data 4 is as an opening of higher education advertorial in English. This paragraph has four clauses that has a similarity with data 3. Both of the paragraphs as higher education advertorial has a similar pattern; that is reiteration pattern or Type 1 (as described by Paltridge, 2000) and Type 2 (as described by Deterding and Poedjosoedarmo, 2001). The data 4 which is similar to data 3 , it has four clauses containing ideational or topical theme of each.

\section{CONCLUSION}

The data analyzed are in both the higher education advertorial in Bahasa Indonesia and English data. It is found that the thematic progression found in English and Bahasa Indonesia has different pattern. The thematic progression in Bahasa Indonesia higher education advertorial is zigzag pattern while the thematic progression in English higher education advertorial is reiteration pattern.From the data draws in Data 1 up to 4 above, it is described that each data has different number of clauses. From the analysis, all the clauses of each data contain ideational or topical theme of each.

\section{References}

Blood, T. \& Bloor, M. 2004. The Functional Analysis of English. London: Arnold.

Brown, C., \& Waltzer, H. 2004. Organized interest advertorials responding to the $9 / 11$ terrorist attack and other national traumas. Harvard International Journal of Press/Politics, 9(4): 25-48.

Deterding, D. \& Poedjosoedarmo, G. 2001. The Grammar of English. Singapore: Prentice Hall.

Gerot, L. \& Wignell, P. 1995. Making Sense of Functional Grammar. Sydney: Gerd Stabler.

Halliday, M.A.K. 1994. An Introduction to Functional Grammar. Sydney: Gerd Stabler.

Halliday, M.A.K. \& Matthiessen, C.M. 2004. An Introduction to Functional Grammar. Sydney: Gerd Stabler.

Halliday, M.A.K. \& Matthiessen, C.M. 2006. Construing Experience through Meaning. London: Continuum.

Iriantara, Y. \& Surachman, Y. 2011. Public Relation Writing: Pendekatan Teoretis dan Praktis. Bandung: PT. Remaja Rosda Karya.

Ju-Pak, K., Kim, B. \& Cameron, G. T. 1995. Trends in the use and abuse of advertorial advertising in magazines. Mass Comm Review. 22(3-4): 112-128.

Kim, B., Pasadeos, Y. \& Barban, A. 2001. On the deceptive effectiveness of labeled and unlabeled advertorial formats. Mass Communication and Society. 4(3): 265-281.

Mulyana, D. 2012. Cultures and Communication. Bandung: PT. Remaja Rosdakarya.

Paltridge, B. 2000. Making Sense of Discourse Analysis. Queensland: Gerd Stabler.

Pamungkas, K., \& Abdulah, R. 2017. Linguistics-Based Pharmaceutical Product Naming Methods: A Morphological Study on OTC Medicine Products in Indonesia. Asian Journal of Pharmaceutical and Clinical Research. 10(14): 108-112. Doi: http://dx.doi.org/10.22159/ajpcr.2017.v10s2.19512

Pamungkas, K., Mita Amalia, R., Lesmana, R., Kadarisman, A., \& Rustandi, D. 2018. Psychological Subject in News Headlines of University Websites in Indonesia: An Applied Linguistics Perspective. International Journal of Applied Linguistics and English Literature, 7(3): 78-84. Doi:http://dx.doi.org/10.7575/aiac.ijalel.v.7n.3p.78

Sharifian, F. 2016. "Glocalisation" of the English Language: A Cultural Linguistics Perspective, Kemanusiaan, 23(2): $1-17$ 
Stout, P. A., Wilcox, G. B. \& Greer, L. 1989. Trends in magazine advertorial use. Journalism Quarterly. 66 (4): $960-$ 964.

Sujatna, E.T.S. 2012. Applying Systemic Functional Linguistics to Bahasa Indonesia Clauses. International Journal of Linguistics. 4(2): 134-146. Doi: https://doi.org/10.5296/ijl.v4i2.1506

Sujatna, E.T.S. 2013. Understanding Systemic Functional Linguistics. Bandung: Unpad Press

Sukma, B.P. \& Sujatna, E.T.S. 2014. Interpersonal Metadiscourse Markers in Opinion Articles: A Study of Texts Written by Indonesian Writers. International Journal of Applied Linguistics \& English Literature. 3(2): 16-21. Doi: http://dx.doi.org/10.7575/aiac.ijalel.v.3n.2p.16 